\title{
Corporate Governance-Firm Performance Relationship: Empirical Evidence from African Countries. A Principal Components Analysis
}

\author{
Olaniyan S. Olajide (Ph.D.) ${ }^{1} \quad$ Soetan R. Funmi (Ph.D.) ${ }^{2} \quad$ Olabiyi Kehinde A (Ph.D.) ${ }^{1}$ \\ 1.Department of Economics, Osun State University, Osogbo, Nigeria \\ 2. Departments of Economics, ObafemiAwolowo University, Ile-Ife, Nigeria
}

\begin{abstract}
This study investigated the relationship between corporate governance and firm performance, with evidence from Africa countries. The review of empirical studies from African countries had established a relationship between corporate governance and firm performance without consensus on a particular kind of relationship; while the result of the analysis using data on the return on assets, returns on equity, price earnings ratio, Tobin's Q and constructed Performance Index as measures of firm performance and ownership structure as a measure of corporate governance revealed that corporate governance has a positive significant relationship with firm performance in Nigeria. The study concluded that though the agency costs of firms are very high, sound corporate governance is usually responsible for the positive performance of firms across African countries.
\end{abstract}

Keywords: Corporate Governance, Agency theory, Firm Performance.

DOI: $10.7176 / \mathrm{EJBM} / 12-17-07$

Publication date:June 30th 2020

\subsection{Introduction}

By definitions, corporate governance can be viewed from two perspectives, namely a narrow and a broad perspectives. In a narrow way, it can be viewed merely as being concerned with the mode and structures within which a firm or enterprise receives its basic orientation and direction, Rwegasira, (2000). In a broad perspective, corporate governance can be regarded as being the heart of both a market economy and a democratic society, Sullivan, (2000). According to the narrow definition, corporate governance is described in term of issues relating to shareholders protection, management control and the popular principal-agency problems of economic theory. In another vein, Sullivan, (2000), a proponent of the broader perspective definition used the examples of the resultant problems of the privatization crusade that emerges through developing countries from 1980s, as well as the transition economies of the former communist countries in the 1990s, to define corporate governance as issues of institutional, legal and capacity building as of firms, Oyejide and Soyibo, (2000).

Also, corporate governance can be defined as one of the important elements for improving economic performance, growth as well as enhancing investor confidence. Akinpelu, (2010). Corporate governance therefore involves a set of relationships among a firm's management, its board, its shareholders and other stakeholders such as employees, customers, communities where they operate, and so on. In addition, corporate governance provides the structure through which the objectives of the firms are set and the ways of attaining those objectives and monitoring performance are also determined, Akinpelu, (2010).

Therefore, this study examine the relationship between corporate governance and firm performance across African countries.

\subsection{Literature Review \\ Corporate Governance Mechanisms \\ 2.1 Ownership Structure}

Ownership and control cannot be completely separated within any firm. The controllers always have some degree of ownership of the equity of the firms they control, while some owners, because of the size of their equity positions, effectively have great measure of control over the firms they own. Thus, ownership structure (i.e. the identities of a firm's equity holders and the sizes of their positions) can be described as a potentially important element of corporate governance, Dennis and McConnell, (2004). However, it is normal to presume that greater overlap between ownership and control should lead to a reduction in conflicts of interest and, therefore, to higher firm value, but the relationships between ownership, control, and firm value are more complicated than that. Ownership by a firm's management, for example, can serve to better align managers' interests with those of the firm's shareholders. However, to the extent that managers' and shareholders' interests are not fully aligned, higher equity ownership can provide managers with greater freedom to pursue their own objectives without fear of reprisal, that is, it can entrench managers Niyubahwe, (2006); Akinpelu, (2010). 


\subsection{Boards of directors}

Most Corporations in most countries have boards of directors. According to theory, the board of directors is specifically charged with responsibility of representing the interests of shareholders. The board exists primarily to hire, monitor, and compensate management, all with an eye towards maximizing shareholder wealth. Though, the board is an effective corporate governance mechanism in theory, in practice its value is less clear, Dennis and McConnell, (2004); Akinpelu, (2010).

Boards of directors in the most economies include some of the very insiders who are also to be monitored, in fact, in some cases they (or parties sympathetic to them) represent a majority of the board, and it is common that $\mathrm{CEO}$ of the firm is also the chairperson of the board. Also, the mode of the selection process for board members is such that management often has a strong influence in determining who constitute the board member. The empirical studies have revealed board composition and executive compensation as primarily board-related issues. The board composition characteristics of interest include the size and structure of the board, that is, the number of directors that comprise the board, the fraction of these directors that are outsiders, and whether the CEO and chairperson positions are held by the same individual, Dennis and McConnell, (2004); Akinpelu, (2010).

Fama and Jensen, (1983) noted that outside directors tend to be more effective monitors of management than inside directors because they are generally key decision makers at other firms who are concerned with their reputations in the managerial labor market. As Fama and Jensen, (1983) have noted, outside directors signal their abilities as key decision makers through their board decisions. Weisbach, (1988) also maintains that inside directors are also likely to be less effective monitors because it can be costly for them to challenge the CEO to whom their careers are tied. Empirical evidence is consistent with these arguments. For instance, Weisbach, (1988) reported that outside directors are more likely than inside directors to replace a poorly performing CEO, Borokhovich, (1996) found that outside directors are also more likely to replace a fired CEO with an executive from outside the firm. They argued that successors from outside the firm are more willing to break with the failed policies of their predecessors.

However, if outside directors are more likely than inside directors to replace a poorly performing CEO and to appoint an executive from outside the firm, then the increase in outside director representation and the extensions of their monitoring role should be accompanied by increases in the strength of the negative relation between firm performance and CEO turnover and in the frequency of outside succession (Husson, (2001); and Niyubahwe, (2006)).

\subsection{Agency Theory}

The agency theory can be traced back to Berle and Means (1932). Other researchers traced it back to Jensen and Meckling (1976) and others to Adam Smith's influential book 'Wealth of Nations', (1976). Adam smith identified the agency problem of firm by pointed out that the company directors are not likely to be very careful with other people's money like with their own. The theory emphasized on the separation of the ownership of a firm and control over the firm's action. According to the theory, shareholders own the firm, but the managers control it. On the other hand, Jensen and Meckling described agency relationship as a form of contract between the owner of the firm and its managers, where the owner (principal) engage agent (managers) to manage the firm on their behalf. As part of this contract, the owner of the firm must delegate decision-making authority to the management. However, the governance of firm is based on the conflicts of interest between the ownership of the firm and the managers, Jensen and Meckling, (1976).

Also, Coyle, (2003) noted that since shareholder ownership is supported by company law in developed countries, then he emphasized that the board of directors should govern the company in the best interest of the owners, that is the shareholders. This denotes that the sole objective of the firm is the maximization of the profits of the shareholders, in form of share price, dividend payment, and firm growth. The board of directors should be accountable to the owners of the firm (shareholders), who have power to remove them from their offices because of poor performance. Even in the revised edition on corporate governance principle worldwide, the International Corporate Governance Network (ICGN), (2005), emphasizes that the overriding objective of the firm is to optimize the return its shareholders and that the corporate governance practices should ensure that boards focus their attention on this main objective, Akinpelu, (2010).

\subsection{Stakeholder Theory}

An alternative view of the Agency theory is the Stakeholder theory which states that the objective of the corporate governance is not just to meet the demand of the shareholders, but also to have regard for the interest of other individual, agents and group who have a stake in the firm, including the public at large. This is because some researchers argued that the objective of the principal-agent relationship appears to focus mainly on the interest of the shareholders. That is, managers are solely concern with shareholders who are interested only in short-term benefit and consequently neglect the long term benefits. Blair (2005) described this as 'market myopia.

According to OECD, (2004), there is a public policy perspective towards corporate governance, as well as a 
corporate perspective. That is, 'from a public policy perspective, the corporate governance is about nurturing enterprise while ensuring accountability in the exercise of power and patronage by firms. The role of public policy is to provide firms with the incentives and discipline to minimise the divergence between private and social returns and protect the interests of stakeholders'. Stakeholder theory began in 1970s and one of the management discipline expositions of the stakeholder theory was Freeman, who enacted the general theory of firm, and incorporating the corporate accountability to many stakeholders, Freeman, (2001). Since then, the stakeholder theory has received a wide attention, across wide disciplines. The importance of firms in the public has received great attention, with their effects on employees, the local environment, the urban communities, and their shareholders. Environmental and social entities have collected information on firms' activities and have focused on firms that have treated their stakeholder in unethical ways, Akinpelu, (2010).

According to stakeholder's theory, corporate governance can be described as ways of achieving a balance of economic and social objectives and a balance between communal and individual objectives. The theory further emphasizes that corporate governance should recognize the importance of the economic imperative being face by firms in the competitive environment, and should encourage efficient use and allocation of scarce resources through proper investment strategy. It should also involve proper accountability from board of directors to shareholders, in giving stewardship of their offices regarding the scarce resources entrusted into their hand, and also in the interest of other stakeholders who may be non-financial members of the firm, Freeman, (2004); Kiel and Nicholson, (2003); John and Senbet, (1998); Akinpelu, 2010.

According to stakeholder's theory, the major objective of corporate governance mainly, should be to recognize and protect the interests of other people, firms, and society in the day to day decision and activities of the firm. However, the major problem with stakeholder theory is that since company law provides certain rights and some legal duties for both shareholder and board of directors toward their firm. There have to be company legislation in support of stakeholder theory for it to work. The view of the supporters of stakeholder theory is called the Pluralist approach, Freeman, (2004); Kiel and Nicholson, (2003); John and Senbet, (1998); Akinpelu, 2010.

In addition, Pluralist approach states that the productive and cooperative relationship in firm will only be optimized if the directors are allowed or obliged to balance the interest of the shareholders with the interest of other stakeholders who are related to the firm. It should be noted that if the stakeholder is well accommodated in the company law, it is likely that most circumstances, the interest of stakeholders will take credence over shareholders' interest but the director will be allow to this stance. Also, it should be taken into cognizance that company law cannot protect all the interest of the shareholders as done by employment law, health safety, and environmental law, Freeman, (2004); Kiel and Nicholson, (2003); John and Senbet, (1998); Akinpelu, 2010.

\subsection{Empirical Evidence on Corporate Governance and Firm Performance from African Countries.}

In Egypt, Mohammed Omeran, 2008 conducted research on the effect of the post-privatization programme on corporate governance and firm performance. The study sampled 52 newly privatized firms from Egypt over the period of 1995-2005. Using ownership structure that results from privatization and its evolution; the determinants of private ownership concentration; the impact of private ownership concentration, ownership; identity and board composition as a proxy for corporate governance on firm performance measured by Return on sales (ROS), ROA, ROE and Tobin's Q. The regression analysis revealed a positive relationship between corporate governance and firm performance. This implies that the state gives up the control over time to the private sector, but still controls, on average, more than 35 percent of firms. Also Firm size, sales growth, industry affiliation, and timing and method of privatization were found to play a key role in determining private ownership concentration. Ownership concentration and ownership identity, in particular foreign investors, were found to have a positive relationship with firm performance, while employees ownership concentration has a negative relationship with firm performance. The higher proportion of outside directors and the change in the board composition following privatization also showed a positive relationship with firm performance. The study concluded by noting some important policy implications which include that private ownership by foreign investors seem to add more value to firms; while selling state-owned enterprises (SOEs) to employees is not recommended. Also, the state was admonished to release control and allow for changes in the board of director following privatization as changing ownership, indeed might not have an impact on firm performance unless it is coupled with new management style.

Also in Ghana, Kingsley Tornyeva, 2012, investigated the relationship between corporate governance and the financial performance of all insurance firms in Ghana. The secondary data was sourced from the national insurance commission and the primary data through the administration of interview questionnaires. The study used ROA, ROE, and corporate social responsibility (CSR) as a proxy for firm performance, board factors of firm and ownership variables were used to capture corporate governance. Using panel data analysis, the findings showed that large board size, board skill, management skill, longer serving CEOs, size of audit committee, audit committee independence, foreign ownership, institutional ownership, dividend policy and annual general meeting are positively related to firm performance of insurance companies in Ghana. The study enjoyed insurance companies to adopt good corporate governance practices to both enhance their firm performances and also to 
protect the interest of their shareholders. Also the regulatory authorities are advised to ensure compliance with good governance practice and to apply the appropriate punishments for non- compliance in order to ensure the growth and development of the insurance industry in Ghana.

Similarly in Kenya, Vincent O. Ongore, (2011), examined the relationship between ownership, board and manager characteristics and firm performance. Using a sample of 54 firms listed at the Nairobi Stock Exchange (NSE). The study used ownership concentration, ownership identity, board effectiveness and managerial discretion as measurement for corporate governance. The typical ownership identities at the NSE are government, foreign, institutional, manager and diverse ownership forms. Firm performance was measured using

Return on Assets (ROA), Return on Equity (ROE) and Dividend Yield (DY). Using the methodology of Logistic Regression and Stepwise Regression, the paper reveals a positive significant relationship between foreign, insider, institutional and diverse ownership forms, and firm performance. However the findings showed a significant negative relationship between ownership concentration and government, and firm performance. The role of boards was found to be of very little value, mainly due to lack of adherence to board member selection criteria. The results also revealed a positive significant relationship between managerial discretion and performance. Collectively, these results are consistent with relevant literature with regard to the implications of government, foreign, manager (insider) and institutional ownership forms, but significantly different concerning the impact of ownership concentration and diverse ownership on firm performance.

\subsection{Empirical Evidence on Corporate Governance and Firm Performance from Nigeria.}

In Nigeria, Adenikinju and Ayorinde, (2001) researched on "Ownership structure, corporate governance and corporate performance: The case of Nigerian quoted companies". The study used data on the NSE to examine the relationship between firm performance (measured by Tobin's Q) and corporate governance (measured by insider ownership and ownership concentration). The study found no significant relationship between firm performance, ownership concentration and managerial shareholding using OLS. Ahmadu Sanda, (2005), examined "The relationship between Corporate governance mechanisms (director's shareholding, board size, ownership concentration, and leverage) and firm financial performance (measured by Tobin's Q) in Nigeria". Using a sample of 93 firms, and regression analysis, the study found a negative significant relationship between board size and firm performance. Also, Tanko. 2007, examined the relationship between corporate governance and firm performance. The study used ROE, Net profit margin, sales growth, Dividend yield, and Stock price/value as a proxy for firm performance, and board independence, board size, audit independence, ownership, and the progressive practices of the company as a measurement for corporate governance. The study found a positive board size and firm performance, and also found that on average, 30\% of board composition are from outside, which shows that the board is dependent. The study also found that when a CEO serve as the chairman of the firm, the firm performance reduces, and therefore recommends an average of about 10-15 board member for firm, and that the position of chief executive and board chairman should be separated.

Also Kajola (2008) examined the relationship between corporate governance and firm performance among 20 non-financial firms using OLS. The sample period was between 2000- 2006. Board size and CEO status were used to capture corporate governance and Tobin's Q to measure firm performance. The study found board size to be positively related to firm performance, while CEO status was negatively related to firm performance. Also, Uadiale, (2010) researched on the relationship between corporate governance and firm performance among 30 firms in 2007 using ordinary least square. Director's shareholding, CEO status, and board size were used as a proxy for corporate governance, while Tobin's Q was used for firm performance. The study found both CEO status and board size to be positively related to firm performance while director's shareholding was found to be negatively related to firm performance. Furthermore, Babatunde (2009) examined the relationship between corporate governance and firm performance among 62 firms, using panel data analysis. Firm performance was proxy by Tobin's Q, while corporate governance was measured by board size and managerial shareholding. The study found board size to be positively related with firm performance, while managerial shareholding was negatively related with firm performance.

\subsection{Research Methodology \\ 3.1 Model specification}

This study adopts the model used by Kajola, (2008), Onaolapo, (2010), Ali, (2011), and Nour, (2012) because the control variables in the model are consistent with standard capital structure and corporate governance theories; therefore the model to be used is as follows:

$Y_{\text {it }}=\alpha_{i t}+\beta_{1} X_{i t}+\beta_{2} Z_{i t}+\mu_{i t}+\varepsilon_{\text {it }}$

where:

Equ (1)

$Y_{\text {it }}$ represents firm performance

$\mathrm{X}_{\mathrm{it}}$ is a vector of corporate governance characteristics,

$\mathrm{Z}_{\mathrm{it}}$ represents control variables 
$\alpha_{i t}$ constant term and $\beta_{1}$ and $\beta_{2}$ and $\beta_{3}$ are coefficient of explanatory variables.

$\mu_{\text {it }}$ is the unobserved firm specific effect and

$\varepsilon_{i t}$ is the error term. It has zero mean, constant variance and is non-auto correlated.

Logarithms of both dependent and independent variables are taken because of the possibility of non-linear relationship between capital structure, corporate governance and firm performance.

\subsection{Source of Data}

This study used secondary data purposively sampled from Nigerian Stock Exchange (1996-2017). A sample of seventy two non-financial quoted firms was purposively selected out of one hundred and seventy five quoted nonfinancial firms on Nigerian Stock Exchange from Agricultural sector, Automobile and Tyre, Breweries, Building and Materials, Chemical and Paints, Computer and office Equipment, Conglomerates, Construction, Engineering Technology, Food/Beverage and Tobacco, Health cares, Industrial/Domestic product, Packaging, Petroleum marketing, Printing and Publishing, Real Estate, Second-tier securities and Textiles.

\subsection{Measurement of variables}

Performance Index represents firm performance computed through principal factor analysis.

Assets Turnover is Sales/Total Asset

Size represents the Natural logarithm of total assets

Asset Tangibility is Net Fixed Asset/Total Asset

Growth is the change in the natural logarithm of total asset.

Own is the ownership concentration which is the proportion of the shares owned by the largest shareholder. It takes the value 0 or 1 .

Tbm is total board member which is the number of directors on the board.

\subsection{Result and Discursion}

Regression analysis and Discursion on Corporate Governance and Firm Performance.

Table 4.1 shows the regression analysis between corporate governance and firm performance. The first column of table 4.10 below reports the regression result between firm performance measured by ROA and explanatory variables. The coefficient of determination $\left(\mathrm{R}^{2}\right)$ reveals that $75.02 \%$ of the firm's return on asset is explained by the variables in the model. The model is statistically significant at 5\% level. The table also reveals that the firm performance measured by return to assets in the previous year has a negative relationship on the performance of firm in the current year. This implies that one percent decrease in the performance of previous period will induce $14.55 \%$ increase in the performance of current period.

Also, corporate governance measured by ownership concentration and total board member have positive relationships with ROA but not significant. This shows that one per cent increase in both ownership concentration and total board member will induce 30.83 per cent and 18.44 per cent increase in firm performance measured by ROA. This finding is consistent with Uadiale, (2010); Babatunde, (2009); Kajola, (2008); Tanko, (2007); Ahamadu, (2005); Kingsley, (2012); Mohammed Omeran, (2008); Khaliq Ur Rehman Cheema, (2013); Pankaj Vashhey, (2012); Black, (2001); Beiner, (2006); Black, (2003); La Porta, (2002); Drobet, (2003); Selvaggi and Upton, (2008); Brown and Caylor,(2004); and Gompers, (2003). These studies witness the effect of global financial crisis on corporate governance and firm performance at the same period of study. However, this finding refutes Vincent Ongore, (2011); Bita Mashayeyekhi, (2008); Yermack, (1996); and Bauer, (2004). This could be due to differences in methodological approaches.

Furthermore, asset turnover revealed a positive and significant relationship to ROA at $5 \%$ level of significance. This shows that one per cent increase in asset turnover will induce 38.79 per cent increase in firm performance measured by ROA. This also shows that asset turnover is an important determinant of firm performance. Firm size however has a negative and significant relationship with ROA at 5\% level of significance. This implies that one per cent decrease in firm size will induce 147 per cent increase in firm performance measured by ROA. Growth and asset tangibility also reveal a negative insignificant relationship with return on asset. 
Table 4.1: Difference and System GMM of Firm Performance and Corporate Governance.

\begin{tabular}{|c|c|c|c|c|c|}
\hline & \multicolumn{5}{|c|}{ Dependent Variable } \\
\hline & $\mathrm{ROA}$ & $\mathrm{ROE}$ & $\mathrm{ES}$ & TOBIN'S Q & PERF. INDEX \\
\hline L1 & $\begin{array}{c}-.145556 * * \\
(-2.80)\end{array}$ & $\begin{array}{c}-.153017 * * \\
(-3.69)\end{array}$ & $\begin{array}{c}-.180150 * * \\
(-2.93)\end{array}$ & $\begin{array}{c}-.106361 * * \\
(-2.43)\end{array}$ & $\begin{array}{c}1.62 \mathrm{e}-15^{* *} \\
(22.91)\end{array}$ \\
\hline Own & $\begin{array}{c}.308316 \\
(1.18)\end{array}$ & $\begin{array}{c}.2920688 \\
(1.17)\end{array}$ & $\begin{array}{c}.0355099 \\
(0.10)\end{array}$ & $\begin{array}{c}.856256^{* *} \\
(2.11)\end{array}$ & $\begin{array}{c}1.96 \mathrm{e}-15^{* *} \\
(4.39)\end{array}$ \\
\hline Tbm & $\begin{array}{c}.1844686 \\
(0.42) \\
\end{array}$ & $\begin{array}{c}.4081349 \\
(0.93) \\
\end{array}$ & $\begin{array}{c}.8846559 * * \\
(-0.46) \\
\end{array}$ & $\begin{array}{c}-.9631606^{*} \\
(-1.77) \\
\end{array}$ & $\begin{array}{c}-7.84 \mathrm{e}-17 \\
(-0.92)\end{array}$ \\
\hline Tov & $\begin{array}{c}.387965^{* *} \\
(6.53) \\
\end{array}$ & $\begin{array}{c}.395070 * * \\
(6.55) \\
\end{array}$ & $\begin{array}{c}.235259^{* *} \\
(2.90) \\
\end{array}$ & $\begin{array}{c}.0574226 \\
(0.58) \\
\end{array}$ & $\begin{array}{c}-1.35 \mathrm{e}-23^{* *} \\
(-2.72) \\
\end{array}$ \\
\hline Size & $\begin{array}{c}-1.479773^{*} \\
(-9.20)\end{array}$ & $\begin{array}{c}-1.45531 * * \\
(-8.48)\end{array}$ & $\begin{array}{c}-.4371381 * * \\
(-2.04)\end{array}$ & $\begin{array}{c}-1.24283 * * \\
(-4.62)\end{array}$ & $\begin{array}{c}-3.47 \mathrm{e}-16^{* *} \\
(-3.89)\end{array}$ \\
\hline Growth & $\begin{array}{c}-.0213623 \\
(-0.63)\end{array}$ & $\begin{array}{c}-.0290422 \\
(2.32)\end{array}$ & $\begin{array}{c}.011851 \\
(0.27) \\
\end{array}$ & $\begin{array}{c}-.0820061 \\
(-1.58)\end{array}$ & $\begin{array}{c}-5.41 \mathrm{e}-16^{* *} \\
(-7.06) \\
\end{array}$ \\
\hline Tang & $\begin{array}{c}-.0967347 \\
(-1.40)\end{array}$ & $\begin{array}{c}-1.04725^{* *} \\
(-15.02)\end{array}$ & $\begin{array}{c}-.1213204 \\
(-1.30)\end{array}$ & $\begin{array}{c}.382925 * * \\
(3.35)\end{array}$ & $\begin{array}{c}-8.59 \mathrm{e}-18^{* *} \\
(-3.47)\end{array}$ \\
\hline cons. & $\begin{array}{c}.7631993 \\
(0.58) \\
\end{array}$ & $\begin{array}{c}.9994053 \\
(0.75) \\
\end{array}$ & $\begin{array}{c}5.18269 * * \\
(3.08) \\
\end{array}$ & $\begin{array}{c}9.36582 * * \\
(5.16) \\
\end{array}$ & $\begin{array}{c}2.01 \mathrm{e}-15^{* *} \\
(1.50)\end{array}$ \\
\hline Instrument Rank & 433 & 431 & 440 & 511 & 586 \\
\hline J-Statistics & $609.17 * *$ & $630.97 * *$ & $606.63 * *$ & $668.65 * *$ & $3.6 \mathrm{e}+06^{* *} *$ \\
\hline No of observation & 477 & 475 & 491 & 607 & 993 \\
\hline $\mathrm{R}^{2}$ & 0.7502 & 0.6545 & 0.7833 & 0.8210 & 0.5209 \\
\hline $\mathrm{F}$ & $40.24 * *$ & $25.31 * *$ & $48.43 * *$ & $61.47 * *$ & $128 * *$ \\
\hline
\end{tabular}

$*, * *$ indicate $10 \%$ and $5 \%$ level of significance. Figures in parenthesis are Z-statistics

Sources: Data Analysis

Also, column two of Table 4.1 reveals the regression result between ROE and the explanatory variables. The coefficient of determination $\left(\mathrm{R}^{2}\right)$ shows that $65.45 \%$ of the variation in Return on Equity can be explained by the variation on the explanatory variables in the model. The model is statistically significant at $5 \%$ level. The column reveals that the firm performance measured by return to equity in the previous year has a negative relationship on the performance of firm in the current year. This means that one percent decrease in the performance of previous period will induce 15 per cent increase in the performance of current period.

In addition, the column indicates that corporate governance measured by ownership concentration and total board member have positive relationships with firm performance (ROE) but not significant. This finding is also consistent with Uadiale, (2010); Babatunde, (2009); Kajola, (2008); Tanko, (2007); Ahamadu, (2005); Kingsley, (2012); Mohammed Omeran, (2008); Khaliq Ur Rehman Cheema, (2013); Pankaj Vashhey, (2012); Black, (2001); Beiner, (2006); Black, (2003); La Porta, (2002); Drobet, (2003); Selvaggi and Upton, (2008); Brown and Caylor,(2004); and Gompers, (2003). However, this finding did not support Vincent Ongore, (2011); Bita Mashayeyekhi, (2008); Yermack, (1996); and Bauer, (2004). This could be owing to methodological differences in the analyses. Also, the column two shows that firm size has a negative significant relationship with firm performance measured by ROE at 5\% level of significance. This implies that one per cent decrease in firm size will induce 145 per cent increase in firm performance measured by ROE.

Also, asset tangibility was negatively significant to firm performance (ROE) at $5 \%$ level of significance. This also shows that one per cent increase in asset tangibility will induce 104 per cent increase in firm performance measured by ROE. Growth was negatively related with ROE but not significant. However, asset turnover has a positive significant relationship to ROE at $5 \%$ level of significance, and this shows the importance of asset turnover to firm performance measured by ROE. This also shows that one per cent increase in asset turnover will induce 39.50 per cent increase in firm performance measured by ROE.

In addition, using Earning per Share (ES) as a measure of firm performance in column three of Table 4.10 above shows that corporate governance measured by ownership concentration has a positive relationship with firm performance measured by ES. This implies that one per cent increase in ownership concentration will induce 3.55 per cent increase in firm performance measured by ES. Total board member also has a positive relationship with firm performance (ES) at 5\% level of significance. This shows that one per cent increase in composition of board member will induce 88.47 per cent increase in firm performance measured by ES. This finding is also consistent with Bita Mashayeyekhi, (2008); Tanko, (2007); Yermack, (1996);Ahamadu, (2005); Kingsley, (2012); Mohammed Omeran, (2008); Khaliq Ur Rehman Cheema, (2013); Pankaj Vashhey, (2012); Black, (2001); Beiner, (2006); Black, (2003); La Porta, (2002); Drobet, (2003); Selvaggi and Upton, (2008); Brown and Caylor,(2004); and Gompers, (2003). These studies witness the effect of global financial crisis on corporate 
governance and firm performance at the same period of study. However, this finding did not support Vincent Ongore, (2011); Kajola, (2008), Babatunde, (2009); Bauer, (2004); and Adenikinju, (2001). This could be due to differences in methodological approaches.

Also, firm size has a negative relationship with firm performance measured by ES at 5\% level of significance. This means that one per cent decrease in firm size will induce 43.71 per cent increase in firm performance measured by ES. Asset tangibility also has a negative insignificant relationship with firm performance (ES). However, asset turnover has a positive relationship with firm performance (ES) at 5\% level of significance. This implies that one per cent increase in asset turnover will induce 23.52 per cent increase in firm performance measured by ES. Growth also revealed a positive relationship with firm performance showing the importance of asset growth and turnover in the determination of firm performance.

Furthermore, the table (column three) also revealed that the firm performance measured by earning per shares (ES) in the previous year has a negative significant relationship on the performance of firm in the current year at $5 \%$ level. This denotes that one percent decrease in the performance of previous period will induce $18 \%$ increase in the performance of current period. Also, the coefficient of determination $\left(\mathrm{R}^{2}\right)$ indicates that $78.33 \%$ of the firm's earning per share price is explained by the explanatory variables in the model. The model is statistically significant at $5 \%$ level.

In addition, column four of Table 4.1 above shows the result of regression analysis between Tobin's q and all the explanatory variables. The coefficient of determination $\left(\mathrm{R}^{2}\right)$ reveals that $82.10 \%$ of the variation in Tobin's $\mathrm{q}$ can be explained by the variation on the explanatory variables in the model, and the model is statistically significant at $5 \%$ level of significance. From the table, the firm performance measured by Tobin's q in the previous year has a negative and significant relationship on the performance of firm in the current year at $5 \%$ level of significance. This means that one percent decrease in the performance of previous period will induce $10.6 \%$ increase in the performance of current period.

Also, corporate governance measured by ownership concentration has a positive relationship with firm performance (Tobin's q) at 5\% level of significance. This shows that one per cent increase in ownership concentration will induce 85.62 per cent increase in firm performance measured by Tobin's q. However, total board member has a negative relationship with firm performance (Tobin's q) at $10 \%$ level of significance. This also shows that one per cent decrease in composition of board member will induce 96.31 per cent increase in firm performance measured by Tobin's q. This supports agency theory which states that corporate governance can be used to align the interest of managers with shareholders to improve firm performance. This finding is also consistent with Bita Mashayeyekhi, (2008); Tanko, (2007); Yermack, (1996);Ahamadu, (2005); Kingsley, (2012); Mohammed Omeran, (2008); Khaliq Ur Rehman Cheema, (2013); Pankaj Vashhey, (2012); Black, (2001); Beiner, (2006); Black, (2003); La Porta, (2002); Drobet, (2003); Selvaggi and Upton, (2008); Brown and Caylor,(2004); and Gompers, (2003). These studies witness the effect of global financial crisis on corporate governance and firm performance at the same period of study. However, this finding did not support Vincent Ongore, (2011); Kajola, (2008), Babatunde, (2009); Bauer, (2004); and Adenikinju, (2001). This could be due to differences in methodological approaches.

Also, firm size has a negative relationship with firm performance measured by Tobin's q at 5\% level of significance. This shows that one per cent decrease in firm size will induce 124 per cent increase in firm performance measured by Tobin's Q. Growth also showed a negative insignificant relationship with firm performance measured by Tobin's Q. The relationship between asset turnover and Tobin's q was positive but not significant. Also, the relationship between Tobin's Q and asset tangibility was positive and significant at 5\% level significance. This also shows that one per cent increase in asset tangibility will induce 38.29 per cent increase in firm performance measured by Tobin's Q.

Furthermore, column five of Table 4.1 above shows the result of regression analysis between Performance Index (PI) and all the explanatory variables. The coefficient of determination $\left(\mathrm{R}^{2}\right)$ reveals that $52.09 \%$ of the variation in Performance Index can be explained by the variation on the explanatory variables in the model, and the model is statistically significant at $5 \%$ level of significance. From the table, the firm performance measured by Performance Index (PI) in the previous year has a positive and significant relationship on the performance of firm in the current year at $5 \%$ level of significance. This means that one percent increase in the performance of previous period will induce $1.62 \mathrm{e}-13 \%$ increase in the performance of current period.

Also, corporate governance measured by ownership concentration has a positive relationship with firm performance (PI) at 5\% level of significance. This shows that one per cent increase in ownership concentration will induce 1.96e-13 per cent increase in firm performance measured by Performance Index (PI). However, total board member has a negative relationship with firm performance (PI) but not significant. This also shows that one per cent decrease in composition of board member will induce $7.84 \mathrm{e}-15$ per cent increase in firm performance measured by Performance Index (PI). This supports agency theory which states that corporate governance can be used to align the interest of managers with shareholders to improve firm performance. This finding is consistent with Bita Mashayeyekhi, (2008); Tanko, (2007); Yermack, (1996);Ahamadu, (2005); Kingsley, (2012); 
Mohammed Omeran, (2008); Khaliq Ur Rehman Cheema, (2013); Pankaj Vashhey, (2012); Black, (2001); Beiner, (2006); Black, (2003); La Porta, (2002); Drobet, (2003); Selvaggi and Upton, (2008); Brown and Caylor,(2004); and Gompers, (2003). These studies witness the effect of global financial crisis on corporate governance and firm performance at the same period of study. However, this finding did not support Vincent Ongore, (2011); Kajola, (2008), Babatunde, (2009); Bauer, (2004); and Adenikinju, (2001). This could be due to differences in methodological approaches.

Also, firm size has a negative relationship with firm performance measured by Performance Index (PI) at 5\% level of significance. This shows that one per cent decrease in firm size will induce $3.47 \mathrm{e}-14$ per cent increase in firm performance measured by Performance Index (PI). Growth also has a negative significant relationship with firm performance measured by Performance Index. This shows that one per cent decrease in growth will cause 5.41e-14 increase in firm performance measured by Performance Index (PI). Also, asset turnover has a negative relationship with firm performance (PI) at 5\% level of significance. This shows that one per cent decrease in asset turnover will cause 1.35e-23 increase in firm performance measured by Performance Index (PI).

In addition, asset tangibility has a negative relationship with firm performance measured by Performance Index (PI) at 5\% level of significance. This also shows that one per cent decrease in asset tangibility will induce $8.59 \mathrm{e}-16$ per cent increase in firm performance measured by Performance Index. This provides evidence that the sampled firm did not use their fixed asset composition effectively to increase on their firm performances. This could be due to effect of global financial crisis during the period.

\subsection{Recommendation and Conclusion}

The result of this study shows that corporate governance measured by ownership concentration has a positive significant relationship with firm performance in Nigeria, while composition of board members has a negative significant relationship with the performance of firm. This shows that ownership concentration is an element of corporate governance is very important to firm performance. This call for corporate governance reform in Nigeria, so as to improve the performance of non-financial firms on Nigerian Stock Exchange. The study concluded that though the agency costs of firms are very high, sound corporate governance is usually responsible for the positive performance of firms across African countries.

\subsection{References}

Adeyemi, S.B., and Oboh, C.S., (2011): "The empirical effects of corporate capital structure on the market value of a selection of firms listed on the Nigerian Stock Exchange".

Aghion, P., Dewatripont, M., and Rey, P., (1999): "Competition, financial discipline and growth." Review of Economic Studies, 66, pp 825- 852.

Ang, J.S., Cole, R.A., and Lin, J.W., (2000): “Agency costs and ownership structure.” Journal of Finance, 55, pp 81- 106.

Beiner, S., Wolfgang, D., Markus, M., Schmid and Heinz Z., (2006): “An Integrated Framework of Corporate Governance and Firm Valuation".

Berle, A.A., and Means, G.C., (1932): "The Modern Corporation and Private Property. New York, Macmillan."

Brigham, E., and Gapenski, L., (1996): "Financial Management”. Dallas, Dryden Press.

Dansetz, H., and Lehn, K., (1985): "The structure of corporate ownership: causes and consequences." Journal of Political Economy, 93, pp 1155- 1177.

DeAngelo, H., and DeAngelo., L., (1985): "Managerial ownership of voting rights: A study of public corporations with dual classes of common stock". Journal of Financial Economics, 14: 33-69.

Demirgüç-Kunt, A., and Levine, R., (1996a): "Stock market development and financial intermediaries: stylized facts", The World Bank Economic Review, 10 (2): 291-321.

Demirgüç-Kunt, A. and Levine, R., (1996b): "Stock markets, corporate finance and economic growth: an overview", The World Bank Economic Review, 10: 223-39.

Friend, I., and Lang, L., (1988): "An empirical test of the impact of managerial self-interest on corporate capital structure", Journal of Finance, Vol. 43, pp. 271-81.

Gorton, G., and Rosen, R., (1995): "Corporate control, portfolio choice and the decline of banking." Journal of Finance, 50, pp 1377- 1420 .

Jensen, M., (1986): “Agency costs of free cash flow, corporate finance and takeovers." American Economic Review, 76, pp 323-329.

Jensen, M., (1988): “Takeovers: their causes and consequences." Journal of Economic Perspectives, 2, pp 21- 48.

Jensen, M., and Meckling, W., (1976): "Theory of the firm: managerial behaviour, agency Costs and capital structure." Journal of Financial Economics, 3, pp 11- 25.

Jensen, M., and Ruback, R., (1983): “The market for corporate control: the scientific evidence." Journal of Financial Economics, 11, pp 5- 50.

Kester, W., (1986): “Capital and ownership structure: a comparison of United States and Japanese manufacturing 
corporations", Financial Management, Vol. 15, pp. 5-16.

Kochhar, R., (1996): "Explaining firm capital structure: the role of agency theory vs Transaction cost economics." Strategic Management Journal, 17, pp 713- 728.

La Porta, R., Lopdez-de-Silanes, F., Shleifer, A., and Vishney, R., (2002): 'Investor Protection and Corporate Valuation', Journal of Finance, 57(3), June, p. 1147-1170.

Levin, A., Lin. C.F., and Chu, C.S. J., (2002): "Unit root tests in panel data: Asymptotic and finite-sample properties". Journal of Econometrics, Vol. 108, pp. 1-24.

Mackie- Mason, J (1990): “Do taxes affect corporate financing decisions?” Journal of Finance, 45, pp 1471- 1494.

Min-Tsung, C., (2009): "Relative effects of debt and equity on corporate operating performance: A quantile regression study". International Journal of Management. Vol 26, No.1

Myers, S. C., (2003): "Financing of corporations". In G. M. Constantinides, M. Harris, \& R. Stulz (Eds.), Handbook of the economics of finance, pp. 215-253.

Myers, S.C., and Majluf, N.S., (1984): "Corporate financing and investment decisions when firms have information that investors do not have", Journal of Financial Economics, Vol. 13 No. 2, pp. 187-221.

Pandey, I. M., (1999): “Financial management”(8th ed.). New Delhi: Vikas Publishing House PVT Ltd.

Penrose, E.T., (1959): “The Theory of the Growth of the Firm”. New York, Wiley.

Rappaport, A., (1998): “Creating Shareholder Value: A Guide for Managers and Investors”, $2^{\text {nd }}$ ed., New York, NY, The Free Press.

Rajendran K., (2011): "Effect of corporate governance on capital Structure: a case of the Srilankan listed Manufacturing companies"

Razak, N.H.A., Ahmad, R., and Aliahmed, H.J., (2008): "Government ownership and performance: An analysis of listed companies in Malaysia", Corporate Ownership and Control, vol. 6, no. 2, pp. 434-442.

Roden, D., and Lewellen, W., (1995): "Corporate capital structure decisions: evidence from leveraged buyouts", Financial Management, Vol. 24, pp. 76-87.

Saad, N. M., (2010): "Corporate Governance Compliance and the Effects to capital Structure". International Journal of Economics and Financial, 2(1), 105-114.

Semiu B. A., Collins S. O., (2011): "Perceived Relationship between Corporate Capital Structure and Firm Value in Nigeria".

Senbet, L.W., .and Otchere, I., (2005): "Financial Sector Reforms in Africa : Perspectives on Issues and Policies". Prepared for the Annual World Bank Conference on Development Economics (ABCDE), Dakar, Senegal.

Shoiab, M. M., (2011): "Impact of capital structure on firm`s financial performance: evidence from Pakistan”, Vol. 17(5),pp 56-101.

Weston, J.F., and Copeland, T.E., (1998): "Managerial Finance"2nd Edition, New York, CBS College Publishing.

Worthington, A.C., and West, T., (2001): "Economic Value-Added: A Review of the Theoretical and Empirical Literature ", Asian Review of Accounting, Vol. 9, No. 1, pp. 67-86.

Worthington, A.C., and West, Tracey., (2004): "Australian evidence concerning the information content of economic value-added", Australian Journal of Management, Vol. 29, No. 2, pp. 201- 24. 